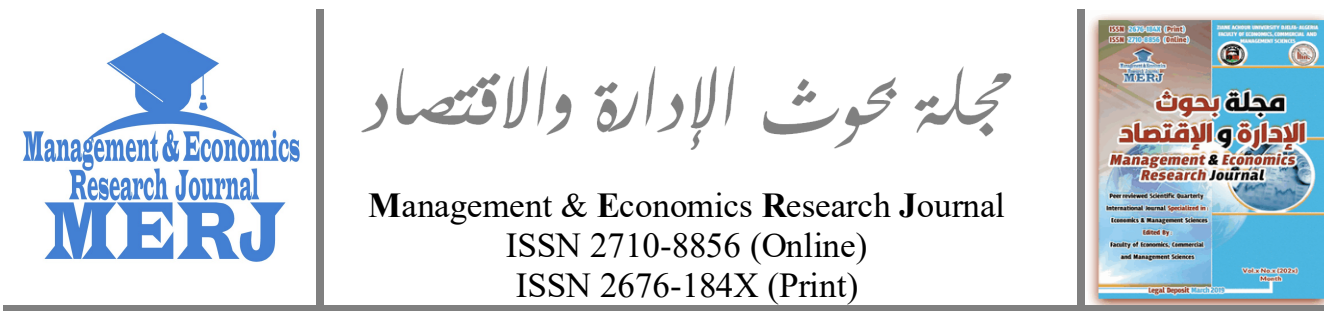

Management \& Economics Research Journal, Vol. 2 No.4 (2020), pp. 27-44

doi https://doi.org/10.48100/merj.v2i4.123

Check for updates

\title{
Performance of Mutual Funds: A Comparative Study of Prominent Multi Capital and Large Capital Funds
}

Abdelkader Derbali ${ }^{1}$ (i), Ahmed K Elnagar ${ }^{2}$ (D), Lamia Jamel ${ }^{3}$ (i), Monia Ben

$$
\text { Ltaifa }^{4}
$$

${ }^{1}$ Assistant Professor, Department of Administrative and Financial Sciences and Techniques, Community College, Taibah University, Medinah (Saudi Arabia)

$\triangle$ derbaliabdelkader@outlook.fr

${ }^{2}$ Assistant Professor, Department of Administrative and Financial Sciences and Techniques, Community College, Taibah University, Medinah (Saudi Arabia)

$\triangle$ ahmed_karam@tourism.suez.edu.eg

${ }^{3}$ Assistant Professor, Department of Finance and Economics, College of Business

Administration, Taibah University, Medinah (Saudi Arabia)

$\triangle$ lajamel@yahoo.fr

${ }^{4}$ Assistant Professor, Human Resource Department, Community College in Abqaiq, King Faisal University, Abqaiq (Saudi Arabia)

$\triangle$ monia mbl@yahoo.fr

Received: 03-05-2020

Accepted: 27-08-2020

Published: 22-09-2020

\section{Abstract:}

This paper aims to compare the performance of prominent multicapital and large-capital funds. We examine the performance of 10 prominent funds under both the selected categories analyzed during the study period from 2013 to 2018 . Their performance has also been compared against India's two most diversified benchmark indices, BSE 200 and Nifty 500 . We have also attempted to determine whether there is any considerable difference in the performance of the two categories of funds or not. To do so, we employ a One-way Analysis of Variance (ANOVA) for the comparison of mutual funds as an econometric methodology for a period of study from 2013 to 2018 for a sample of 20 Indian mutual funds. From the empirical findings, we find that the mutual fund schemes under both categories, such as Multi Capital Funds and Large Cap Funds, have generated good returns over the period, with reasonable risk. Therefore, it is

- Corresponding author: Department of Administrative and Financial Sciences and Techniques, Community College, Taibah University, Medinah (Saudi Arabia).

[ $\triangle$ derbaliabdelkader@outlook.fr]

Faculty of Economics, Commercial \& Management

Sciences, Ziane Achour University of Djelfa, BP

3117, Djelfa - Algeria 
safe to conclude that they are a good investment option for an investor. Regarding the performance of these mutual funds, the average monthly returns generated by the funds in each category are numerically different. However, this difference has not been found statistically significant. At the same time, there is no significant difference between these funds and NIFTY 500, as well as these funds and BSE 200 in terms of their returns.

Keywords: Large Cap Funds, Mutual Funds, Multi-Cap Funds, Return, Risk.

JEL Codes: G32, G20, O16.

\section{Introduction}

With the constantly changing scenario of the Indian capital market, avenues for investments in financial assets have changed drastically. In the past, investors (particularly small investors) had limited investment options, e.g., shares, bonds and debentures, post office deposits, bank FDs, etc. Nevertheless, in recent times investors have got many more avenues for this purpose, and mutual funds are one of them.

SEBI (mutual fund) regulations, 1993, define a mutual fund as "A fund established in the form of a trust by a sponsor to raise money by the trustees through the sale of units to the public under one or more schemes for investing in securities in accordance with these regulations."

In the current economic era, the Indian mutual fund industry has emerged as one of the most promising investment opportunities. Investment in financial assets has always been a matter of great importance in an investor's life. No matter how small the savings are, every investor wants to earn a good amount of returns at a sustainable risk rate. Various mutual fund schemes have surfaced to substantiate the diversified financial goals of investors. The investors and the fund managers need to undergo rigorous and constant evaluation regarding the risk \& return of various schemes under purview. It enables the fund managers to identify the strengths and weaknesses of these schemes, which helps them to make improved decisions in the future.

Mutual funds are categorized into various categories, e.g., Large Capital Funds Multi Capital Funds, Mid Capital Funds, Small Capital Funds, ELSS, Index Funds, Balanced Funds, Debt Funds, Liquid Funds, etc. This study is about Multi Capital and Large Capital Mutual Funds. Both these fund categories are very popular among investors. However, an investor's orientation towards risk and return, along with the investment duration, is dominant in deciding which cap to invest in. Generally, Investors with a shorter time horizon, lower threshold towards risk, and 
consideration for steady returns prefer to invest in Large Capital Funds. On the contrary, Multi Capital Funds are chosen by investors with relatively long time horizons, higher risk thresholds, and potentially higher returns.

This research paper analyzes the performance of prominent mutual funds under two important Capital categories, i.e., Multi Capital and Large Capital Funds, based on returns generated over five years. Their performance has also been compared against that of BSE200 and Nifty500. We have also tried to determine whether there is any significant difference in the performance of these funds. From the empirical findings, we can show that this study reveals that the mutual fund schemes under both the categories, i.e., Multi Capital Funds and Large Capital Funds, have generated good returns over the period, and that too with reasonable risk. Therefore, it is safe to conclude that they are a good investment option for an investor.

The rest of our paper is organized as follows: Section two presents a literature review and research hypothesis. Section three describes the econometric methodology utilized in this study. Section four is devoted to the empirical results. Finally, the fifth section included the conclusion of the study.

\section{Literature review}

Many researchers and analysts have conducted various studies on the performance of various mutual fund schemes. Some important studies are mentioned below: Rangasamy and Sathiyapriya (2017) elaborate on a study on the performance evaluation of mutual fund schemes. The study's main objective was to analyze the schemes' risk and return and evaluate the performance of selected mutual funds' equity, debt, and balanced schemes using Treynor, Sharpe, Jensen measure, etc. The study attempted to evaluate various mutual fund schemes with respect to four financial years (20122016).

Pandow (2017) presents a study on India's Performance of Mutual Funds. The study advocates that the industry be confronted with several challenges like low penetration ratio, lack of product differentiation, lack of investor awareness and ability to communicate value to customers, lack of interest of retail investors towards mutual funds, and evolving nature of the industry. Based on the analysis, the study suggests that if the industry has to utilize its potential fully, it must address these challenges.

Agarwal and Mirza (2017) investigated a study on India's riskadjusted performance of the mutual fund industry. The research includes measuring the performance of selected mutual schemes based on risk and 
return and comparing the performance of the selected schemes with the benchmark index to see whether the scheme is outperforming or underperforming the benchmark. In addition, funds were ranked based on performance, and strategies were suggested to invest in a mutual fund.

Nandhini and Rathnamani (2017) developed a study on the performance of equity-based mutual funds (with particular reference to equity large-cap and mid-cap mutual funds). The study focuses on the performance of selected equity large and small-cap mutual fund schemes, and they were analyzed with various risk-return measurement tools such as alpha, beta, standard deviation, and Sharpe ratio.

Damayanti and Cintyawati (2015) conduct a study that aims to determine factors that affect the performance of mutual funds, especially equity mutual funds. Several factors are considered to affect the performance of mutual funds, such as asset under management (AUM), fund age, past performance, asset allocation, turn of the year effect, equity funds with blue-chip or non-blue-chip stocks, equity funds owned by insurance or non-insurance companies, external factors such as the rupee against the US dollar (exchange rate) and investors behavior, etc.

Husain and Sharma (2014) analyze the performance of the equity mutual funds industry against risk-free rates and benchmark returns over five years. The risk-return analysis revealed that out of 10 schemes, three had underperformed the market, while seven were found to have lower total risk than the market, and all the schemes have given returns higher than risk-free rates. The result of regression analysis suggested that benchmark market index return has a statistically significant impact on mutual fund return at a $5 \%$ level of significance.

Choudhary and Chawla (2014) researched the performance evaluation of mutual funds: a study of selected diversified equity mutual funds in India. Through this study, an attempt has been made to analyze the performance of growth-oriented equity-diversified schemes based on return and risk evaluation. The analysis was achieved by assessing various financial tests like Average Return, Sharpe Ratio, Treynor Ratio, Standard Deviation, Beta, and Coefficient of Determination.

Narayanasamy and Rathnamani (2013), in their study, focused on the performance of selected equity large-cap mutual fund schemes in terms of the risk-return relationship. The main objective of the research was to analyze the financial performance of selected mutual fund schemes through statistical parameters such as alpha, beta, standard deviation, r-squared, Sharpe ratio, etc.

Kumar and Kumar (2012) elaborate a study with the prominent 
objective of determining the appropriate Benchmark Index comprising appropriate asset classes of securities to pave the way for precise estimation. The study considers Tax Planning (Equity Linked Savings Scheme-ELSS) funds and selected indices of the National Stock Exchange and Bombay Stock Exchange. The study reveals that broad-based indices that consist of Large-cap, Mid-cap, and Small-cap asset classes would be an appropriate benchmark for evaluating the performance of ELSS funds.

Philips and Kinniry (2010) developed a paper based on Mutual fund ratings and future performance. Their paper addresses two questions surrounding mutual fund rating systems, first, why index funds receive an average rating based on relative quantitative metrics, and second, whether a given performance rating offers actionable information. Specifically, the paper focused on whether higher-rated funds can be expected to outperform lower-rated funds in the future.

Cujean (2020) creates an equilibrium model to explain why few mutual fund directors consistently outperform, even though numerous have great informational benefits. Then, the important ingredient is that executives get investing proposals across proposal communication. The proposal sharing increases the statistical importance of alpha across improved value informativeness. However, it additionally affects welladvised executives to take greater places, which creates their alpha deafening though a considerable portion of executives creates powerful informational benefits, statistical implication, and perseverance of alpha focus in underachieving funds. Cujean (2020) argues that the in-house advancement of proposals cannot clarify these realities.

Badrizadeh and Paradi (2020) propose a new data envelopment analysis (DEA) methodology, such as Mixed Variable DEA (MV-DEA), that offers a method where DMUs with some different cultural assumptions are examined relative to every previous while maintaining their particular attributes. In their paper, Badrizadeh and Paradi (2020) try to assess private pension funds' profitability by contemplating the particular traits of such funds in contrast with mutual funds. The Canadian personal pension funds, controlled by the Federal Government of Canada (FGC), and Canadian open-ended mutual funds were analyzed. Their empirical findings of the novel MV-DEA methodology were related to traditional data envelopment analysis models, demonstrating that the MV-DEA model provided more convincing findings in their paper.

Busse et al. (2020) examine interdependencies among trade costs, portfolio traits, and mutual fund profitability. They employ a new database of real mutual fund transactions. They show that managing for investing 
type, greater funds recognize shorter proportion trade costs than reduced funds. Also, they conclude that bigger mutual funds transaction fewer regularly and hold more extensive stocks to prevent acquiring greater transaction costs aggressively. They conclude that gross returns of greater funds are smaller than those of lesser funds due partly to the attributes of their investments, which indicates that reducing returns to magnitude could occur due to restricted investing prospects because of transaction cost limitations. hypotheses:

Based on the previous literature review, we will test the following

$\mathbf{H}_{01}$ : Selected Multi Capital Funds do not generate significantly different returns.

Ho2: Selected Large Capital Funds do not generate significantly different returns.

H03: Multi Capital and Large Capital funds do not generate significantly different returns.

$\mathbf{H}_{04}$ : There is no significant difference between the returns of MultiCap and Large Cap mutual funds and that of benchmark NIFTY 500.

$\mathbf{H}_{05}$ : There is no significant difference between the returns of MultiCap and Large Cap mutual funds and benchmark BSE 200.

\section{Research methodology}

This study has been conducted keeping in mind the following objectives: To analyze the performance of prominent Large-Cap and MultiCap mutual funds, to evaluate the performance of prominent Large-Cap and Multi-Cap mutual funds regarding two benchmark indices, i.e., BSE 200 and Nifty 500, and to examine whether these funds are significantly different in terms of the return generated by them or not.

For this paper, the following ten prominent mutual funds schemes under each category, i.e., Multi-Cap and Large Cap, have been presented in Table 1.

BSE 200 and Nifty500 have been chosen as the benchmark indices to judge the performance of the selected mutual fund schemes. Relevant data have been collected through authorized websites for five years, from January 2013 to December 2018. 
Table 1. Selected Multi-Cap Funds and Large Cap Funds

\begin{tabular}{l|ll}
\hline Sr. No & Multi Capital Funds & Large Capital Funds \\
\hline 1. & Canara Robeco Equity Diversified & Canara Robeco Blue Chip Equity \\
2. & UTI Equity Fund & Edelweiss Large Cap Fund \\
3. & HDFC Equity Fund - Growth Option & HDFC Top 100 Fund \\
4. & Mirae Asset India Equity Fund & Axis Bluechip Fund - Growth \\
5. & Aditya Birla Sun Life Equity Fund & Invesco India Largecap Fund \\
6. & ICICI Prudential Multicap Fund & UTI Master Share-Growth \\
7. & JM Multicap Fund & ICICI Prudential Bluechip Fund \\
8. & Kotak Standard Multicap Fund & Reliance Large Cap Fund \\
9. & Aditya Birla Sun Life Equity Fund & IDFC Large Cap Fund \\
10. & Franklin India Equity Fund & JM Core 11 Fund \\
\hline
\end{tabular}

Source: Own elaboration

\subsection{Calculation of return}

For this research work monthly return of each mutual fund scheme, understudy has been calculated. In order to calculate monthly return following two Net asset value (NAV) of the fund is considered:

- The opening NAV of the month and

- The closing NAV of the month

The formula for calculating monthly return:

$$
R_{t}=\frac{(\text { Closing NAV of the month-Opening NAV of the month })}{\text { The opening NAV of the month }} \times 100
$$

\subsection{Calculation of risk}

Risk is calculated based on the monthly return of the mutual fund scheme under study. The risk associated with a mutual fund is calculated by using standard deviation as a measure of risk.

The total risk of a mutual fund scheme is measured by calculating the Standard deviation (SD) of the monthly returns using the below mention formula:

$$
S D=\sqrt{\frac{1}{n-1} \sum_{t=1}^{n}\left(R_{t}-\bar{R}\right)^{2}}
$$

Where SD represents standard deviation, $\mathrm{n}$ represents the number of monthly returns, $R_{t}$ represents monthly returns of the mutual fund, and $\overline{\mathrm{R}}$ represents the mean return of the mutual fund.

For the data analysis, Excel and R 3.5.2 software has been used in this study. Descriptive statistics of all the variables have been presented. 
This study uses a One-way Analysis of Variance (ANOVA) and Paired Two-Sample t-test to compare mutual funds. The variance analysis compares the means of $\mathrm{k}$ populations from random and independent samples taken from each of them. These populations are generally variants (or levels $\mathrm{k}$ ) of one or more controlled factors of variation (factors A, B, etc.). ANOVA has another advantage over simple t-tests: it allows us to detect interactions between variables and, therefore, to test more complex hypotheses.

\section{Empirical findings}

It is clear from Table 2 that the maximum average for annual return in the Multi Capital category has been generated by Mirae Asset India Equity Fund (15.12\%), while the minimum return has been generated by Canara Robeco Equity Diversified Fund (10.44\%).

In the Large Capital category, the maximum average annual return has been generated by Reliance Large Capital Fund (14.16\%), while the minimum return has been generated by IDFC Large Fund (9.72\%). Other funds in each category have given a return between the mentioned maximum and minimum values. These returns are good from any perspective. However, at the same time, we should not overlook the fact that there is a risk associated with these returns. Also, we can conclude that Multi Capital funds have returns superior to the returns in the case of Large Capital Funds in the context of our sample. In the same Table, we can remark that the Multi Capital funds are riskier than the Large Capital Funds in the Indian context. So, we can reject the first three hypotheses $\left(\mathrm{H}_{01}, \mathrm{H}_{02}\right.$, and $\mathrm{H}_{03}$ ), which indicate that these elected Multi Capital Funds do not generate significantly different returns, the selected Large Capital Funds do not generate significantly different returns, and the Multi Capital and Large Capital funds do not generate significantly different returns.

Figure 1 presents monthly average returns of NIFTY500, BSE200, Multi Capital Mutual Funds \& Large Capital Mutual Funds. For the Two Benchmark Indices (NIFTY500 and BSE200), the high level of their returns is for the beginning of 2013 and 2015. However, for the Multi Capital Mutual Funds and Large Capital Mutual Funds, the high level of returns is for the beginning of the period of study in 2013, and the low level of returns is for the beginning of 2015 and the end of 2018.

Tables 3 and 4 summarize the Descriptive Statistics of returns for Multi Capital Mutual Funds, Large Capital Mutual Funds, and the Two Benchmark Indices (NIFTY500 and BSE200). From these tables, we can find that the high level of volatility (measured by standard error) of returns 
is for NIFTY500 (0.532923657), followed respectively by Multi Capital Mutual Funds (0.528458551), BSE200 (0.521654236) and Large Capital Mutual Funds (0.515306678). Also, in the mean of returns, we can show that the high level of mean is for Multi Capital Mutual Funds (1.119933239) followed respectively by Large Capital Mutual Funds (0.971223614), NIFTY 500 (0.916050632) and BSE 200 (0.890394425). Additionally, we can find that the high level of the sum of returns is for Multi Capital Mutual Funds (67.19599434) followed respectively by Large Capital Mutual Funds (58.27341683), NIFTY500 (54.96303794) and BSE200 (53.42366553). Then, we can conclude that Multi Capital Mutual Funds in India perform more than Large Capital Mutual Funds. This conclusion is founded on the sample used in this paper.

Then, we apply the One way ANOVA methodology to test whether there is a significant difference between the ten Large Capital mutual funds and ten Multi Capital mutual funds or not in terms of their returns.

Tables 5 and 6 show that within the categories of Capital mutual funds (i.e., large Capital \& multi Capital), there is no statistically significant difference in return generation, i.e., all the mutual funds under these categories generate more or less the same return. Then, we can reject the two last hypotheses $\left(\mathrm{H}_{04}\right.$ and $\left.\mathrm{H}_{05}\right)$, which say that there is no significant difference between the returns of Multi Capital and Large Capital mutual funds, and that of benchmark NIFTY 500 and there is no significant difference between the returns of Multi Capital and Large Capital mutual funds and that of benchmark BSE 200.

Table 7 shows that there is no statistically significant difference in return generation between the categories of Capital mutual funds (i.e., large Capital and multi Capital). In other words, we can say that these categories are more or less the same in generating returns. Based on the results presented in Table 7 , we can accept the first three hypotheses $\left(\mathrm{H}_{01}, \mathrm{H}_{02}\right.$, and $\mathrm{H}_{03}$ ), which indicate that these elected Multi Capital Funds do not generate significantly different returns, the selected Large Capital Funds do not generate significantly different returns, and the Multi Capital and Large Capital funds do not generate significantly different returns. We find a considerable difference between simple descriptive statistics and the ANOVA methodology in this context.

Then, we apply the paired two-sample t-test to test whether the observed values of the variables of these three mutual funds are significantly different from the standard values.

From Tables 8, 9, 10, and 11, it can be seen that at a level of significance of $5 \%$, the p-value is greater or equal to 0.05 . Therefore we 
accept the null hypothesis and conclude that there is no statistically significant difference between the mean returns of NIFTY500 and Large Cap or Multi-Cap mutual fund returns and BSE200 and Large Cap or MultiCap mutual fund returns. Then, we can accept the two last hypotheses (H04 and H05), which say that there is no significant difference between the returns of Multi Capital and Large Capital mutual funds, and that of benchmark NIFTY 500, and there is no significant difference between the returns of Multi Capital and Large Capital mutual funds, and that of benchmark BSE 200. In this case, we conclude an important difference between simple descriptive statistics and the paired two-sample t-test technique.

Table 2. Return and risk of selected funds (monthly calculation)

\begin{tabular}{|c|c|c|c|}
\hline Sr. No & Mutual funds & Average return $(\%)$ & $\begin{array}{l}\text { Total risk } \\
\text { (SD) } \%\end{array}$ \\
\hline \multicolumn{4}{|c|}{ Multi capital funds } \\
\hline 1 & Canara Robeco Equity Diversified Fund & 0.87 & 4.30 \\
\hline 2 & UTI Equity Fund & 1.01 & 3.98 \\
\hline 3 & HDFC Equity Fund - Growth Option & 1.02 & 4.88 \\
\hline 4 & Mirae Asset India Equity Fund & 1.26 & 3.92 \\
\hline 5 & Aditya Birla Sun Life Equity Fund & 1.24 & 4.39 \\
\hline 6 & ICICI Prudential Multicap Fund & 1.14 & 3.82 \\
\hline 7 & JM Multicap Fund & 1.09 & 4.76 \\
\hline 8 & Kotak Standard Multicap Fund & 1.21 & 4.03 \\
\hline 9 & Aditya Birla Sun Life Equity Fund & 1.24 & 4.39 \\
\hline 10 & Franklin India Equity Fund & 1.13 & 3.75 \\
\hline \multicolumn{4}{|c|}{ Large capital funds } \\
\hline 1 & Canara Robeco Blue Chip Equity Fund & 0.86 & 3.92 \\
\hline 2 & Edelweiss Large Cap Fund & 0.95 & 3.89 \\
\hline 3 & HDFC Top 100 Fund & 1.03 & 4.64 \\
\hline 4 & Axis Bluechip Fund - Growth & 1.00 & 3.89 \\
\hline 5 & Invesco India Largecap Fund & 0.95 & 3.75 \\
\hline 6 & UTI Master Share-Growth & 0.82 & 3.64 \\
\hline 7 & ICICI Prudential Bluechip Fund & 1.05 & 3.76 \\
\hline 8 & Reliance Large Cap Fund & 1.18 & 4.27 \\
\hline 9 & IDFC Large Cap Fund & 0.81 & 3.67 \\
\hline 10 & JM Core 11 Fund & 1.07 & 5.82 \\
\hline
\end{tabular}

Source: These are the results based on calculations with the help of monthly data for the selected period (January 01, 2013, to December 31, 2018) 
\begin{tabular}{l|l|l} 
Management \& Economics Research Journal & Vol. 1 No. 4 (2020) & pp. 27-44
\end{tabular}
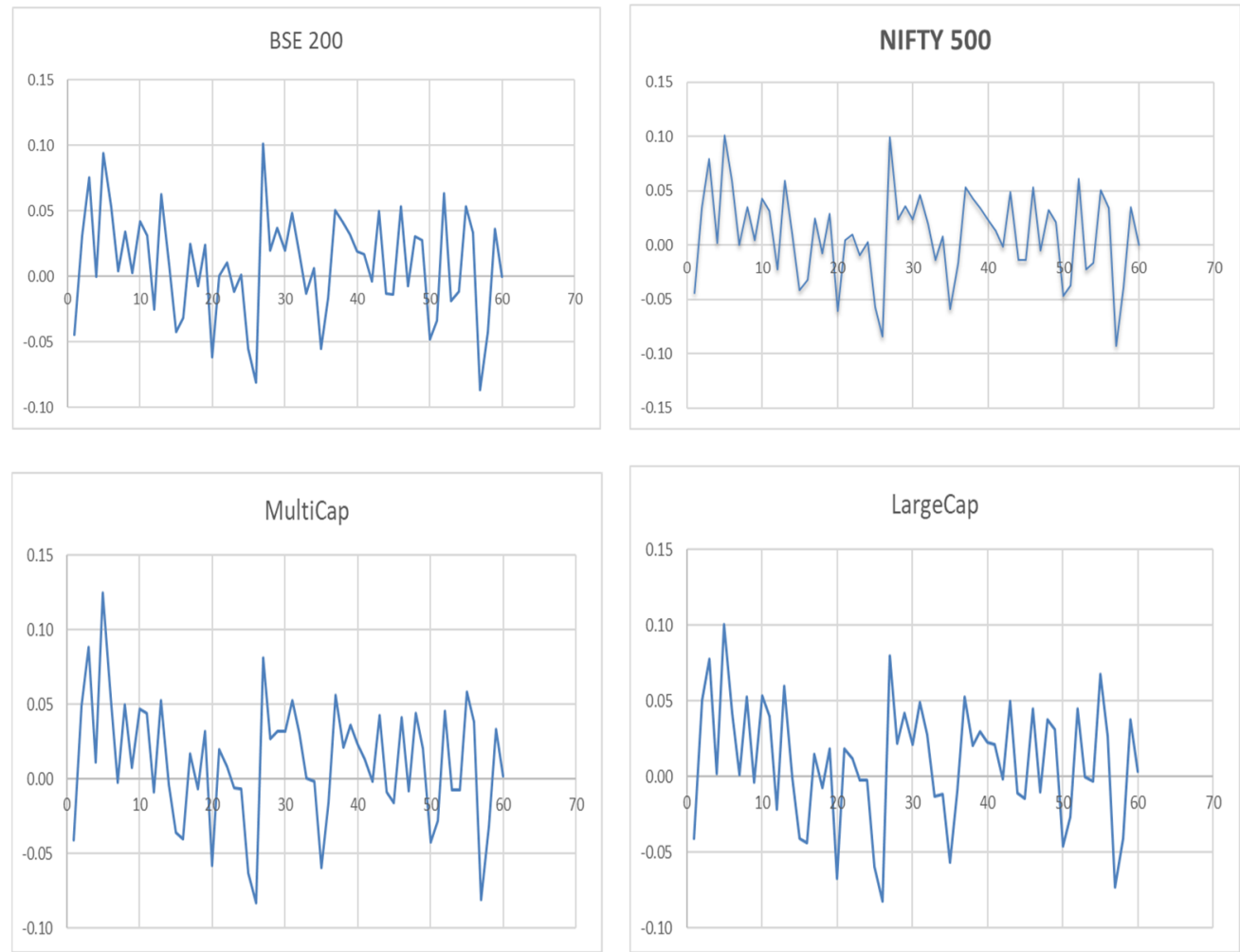

Figure 1. Monthly average returns of NIFTY 500, BSE 200, Multi capital mutual funds \& large capital mutual funds Source: Own elaboration.

Table 3. Descriptive statistics of multi-capital and large-capital mutual funds

\begin{tabular}{llll}
\hline \multicolumn{3}{l}{ Multi-capital mutual funds } & \multicolumn{2}{l}{ Large-capital mutual funds } \\
\hline Mean & 1.119933239 & Mean & 0.971223614 \\
Standard Error & 0.528458551 & Standard Error & 0.515306678 \\
Minimum & -8.299512227 & Minimum & -8.231407745 \\
Maximum & 12.47133963 & Maximum & 10.04124032 \\
Sum & 67.19599434 & Sum & 58.27341683 \\
Count & 60 & Count & 60 \\
\hline
\end{tabular}

Source: Own elaboration. 
Abdelkader Derbali, Ahmed K Elnagar, Lamia Jamel \& Monia Ben Ltaifa
Performance of Mutual Funds: A Comparative Study of

Prominent Multi Capital and Large Capital Funds

Table 4. Descriptive statistics of two benchmar indices i.e. NIFTY 500 \& BSE 200

\begin{tabular}{llll}
\hline NIFTY 500 & \multicolumn{3}{c}{ BSE 200 } \\
\hline Mean & 0.916050632 & Mean & 0.890394425 \\
Standard Error & 0.532923657 & Standard Error & 0.521654236 \\
Minimum & -9.29217849 & Minimum & -8.649465301 \\
Maximum & 10.08907144 & Maximum & 10.12240816 \\
Sum & 54.96303794 & Sum & 53.42366553 \\
Count & 60 & Count & 60 \\
\hline
\end{tabular}

Source: Own elaboration.

Table 5. ANOVA: Single factor for large capital mutual funds

\begin{tabular}{|c|c|c|c|c|c|}
\hline \multicolumn{6}{|l|}{ SUMMARY } \\
\hline Groups & Count & Sum & Average & \multicolumn{2}{|c|}{ Variance } \\
\hline \multicolumn{5}{|l|}{ Canara Robeco Blue Chip Equity } & 15.33711 \\
\hline Edelweiss Large Cap Fund & 60 & 57.05623 & 0.950937 & \multicolumn{2}{|c|}{15.11978} \\
\hline HDFC Top 100 Fund & 60 & 61.94614 & 1.032436 & \multicolumn{2}{|c|}{21.57991} \\
\hline Axis Bluechip Fund - Growth & 60 & 59.92729 & 0.998788 & \multicolumn{2}{|c|}{15.08373} \\
\hline Invesco India Largecap Fund & 60 & 56.99951 & 0.949992 & \multicolumn{2}{|c|}{14.09595} \\
\hline UTI Master Share-Growth & 60 & 48.5027 & 0.818378 & \multicolumn{2}{|c|}{13.23764} \\
\hline ICICI Prudential Bluechip Fund & 60 & 62.98096 & 1.049683 & \multicolumn{2}{|c|}{14.10872} \\
\hline Reliance Large Cap Fund & 60 & 70.54208 & 1.175701 & \multicolumn{2}{|c|}{18.23794} \\
\hline IDFC Large Cap Fund & 60 & 48.5027 & 0.808378 & \multicolumn{2}{|c|}{13.43764} \\
\hline JM Core 11 Fund & 60 & 64.38423 & 1.07307 & \multicolumn{2}{|c|}{33.85397} \\
\hline \multicolumn{6}{|l|}{ ANOVA } \\
\hline Source of Variation & $\mathrm{df}$ & MS & $\mathrm{F}$ & $\mathrm{P}$-value & $\mathrm{F}$ crit \\
\hline Between Groups & 9 & \multirow{3}{*}{$\begin{array}{l}0.85371 \\
17.42924\end{array}$} & 0.048981 & \multirow[t]{3}{*}{0.999982} & 1.895737 \\
\hline Within Groups & 590 & & & & \\
\hline 10290.93 & 599 & & & & \\
\hline
\end{tabular}

Source: Own elaboration. 
Table 6. ANOVA: Single factor for multi-capital mutual funds SUMMARY

\begin{tabular}{|c|c|c|c|c|}
\hline Groups & Count & Sum & Average & Variance \\
\hline $\begin{array}{l}\text { Canara Robeco Equity } \\
\text { Diversified Fund }\end{array}$ & 60 & 51.90193 & 0.865032 & 18.49496 \\
\hline UTI Equity Fund & 60 & 60.47326 & 1.007888 & 15.88318 \\
\hline Option & 60 & 61.02171 & 1.017028 & 23.75977 \\
\hline $\begin{array}{l}\text { Mirae Asset India Equity Fund } \\
\text { Aditya Birla Sun Life Equity }\end{array}$ & 60 & 75.67318 & 1.26122 & 15.34697 \\
\hline Fund & 60 & 74.26742 & 1.23779 & 19.27455 \\
\hline ICICI Prudential Multicap Fund & 60 & 68.42584 & 1.140431 & 14.63812 \\
\hline JM Multicap Fund & 60 & 65.64711 & 1.094119 & 22.68657 \\
\hline $\begin{array}{l}\text { Kotak Standard Multicap Fund } \\
\text { Aditya Birla Sun Life Equity }\end{array}$ & 60 & 72.49056 & 1.208176 & 16.23154 \\
\hline Fund & 60 & 74.26742 & 1.23779 & 19.27455 \\
\hline Franklin India Equity Fund & 60 & 67.79152 & 1.129859 & 14.08982 \\
\hline
\end{tabular}

ANOVA

\begin{tabular}{lllllll}
\hline $\begin{array}{l}\text { Source of } \\
\text { Variation }\end{array}$ & SS & df & MS & F & P-value & F crit \\
\hline Between & & & & & & \\
Groups & 8.689945 & 9 & 0.965549 & 0.053737 & 0.999973 & 1.895737 \\
Within Groups & 10601.12 & 590 & 17.968 & & & \\
Total & 10609.81 & 599 & & & & \\
\hline
\end{tabular}

Source: Own elaboration 
Abdelkader Derbali, Ahmed

K Elnagar, Lamia Jamel \&

Performance of Mutual Funds: A Comparative Study of

Prominent Multi Capital and Large Capital Funds

Table 7. ANOVA: Single factor between multi-cap \& large-cap mutual funds

SUMMARY

\begin{tabular}{lllll} 
Groups & Count & Sum & Average & Variance \\
\hline Multi Cap & & & & \\
Mutual & & 67.195994 & 1.1199332 & 16.756106 \\
Funds & 60 & 34 & 39 & 39 \\
\hline Large Cap & & & & \\
Mutual & & 58.273416 & 0.9712236 & 15.932458 \\
Funds & 60 & 83 & 14 & 32 \\
\hline
\end{tabular}

\begin{tabular}{lllllll}
\hline ANOVA & & & & & & \\
\hline $\begin{array}{l}\text { Source } \\
\text { of }\end{array}$ & & & & & & \\
Variatio & & & & & & \\
$\mathrm{n}$ & $\mathrm{SS}$ & $\mathrm{df}$ & $\mathrm{MS}$ & $\mathrm{F}$ & $\mathrm{P}$-value & F crit \\
\hline Between & 0.6634365 & & 0.6634365 & 0.0405913 & 0.8406756 & 3.9214781 \\
Groups & 78 & 1 & 78 & 56 & 65 & 81 \\
\hline Within & 1928.6253 & & 16.344282 & & & \\
Groups & 18 & 118 & 36 & & & \\
\hline & 1929.2887 & & & & & \\
Total & 55 & 119 & & & & \\
\hline
\end{tabular}

Source: Own elaboration.

Table 8. Paired two-sample t-test for comparison of mean return of the NIFTY 500 and large-cap mutual funds

\begin{tabular}{lll}
\hline & NIFTY 500 & Large Cap \\
\hline Mean & 0.916050632 & 0.971223614 \\
Variance & 17.04045745 & 15.93245832 \\
Observations & 60 & 60 \\
Pearson correlation & 0.97187596 & \\
Hypothesized mean difference & 0 & \\
df & 59 & \\
t Stat & -0.439529003 & \\
P value & 0.66188401 & \\
\hline
\end{tabular}

Source: Own elaboration 
Table 9. Paired Two sample t-test for comparison of mean return of the NIFTY 500 and multi-cap mutual funds

\begin{tabular}{lll}
\hline & NIFTY 500 & Multi Cap \\
\hline Mean & 0.916050632 & 1.119933239 \\
Variance & 17.04045745 & 16.75610639 \\
Observations & 60 & 60 \\
Pearson correlation & 0.975655351 & \\
Hypothesized mean difference & 0 & \\
df & 59 & \\
$\mathrm{t} \mathrm{Stat}$ & -1.739842592 & \\
$\mathrm{P}(\mathrm{T}<=\mathrm{t})$ two-tail & 0.087101034 & \\
\hline
\end{tabular}

Source: Own elaboration.

Table 10. Paired two-sample t-test for comparison of the mean return of the BSE 200 and large-cap mutual funds

\begin{tabular}{lll}
\hline & BSE 200 & Large Cap \\
\hline Mean & 0.890394425 & 0.971223614 \\
Variance & 16.32738851 & 15.93245832 \\
Observations & 60 & 60 \\
Pearson correlation & 0.974761865 & \\
Hypothesized mean difference & 0 & \\
df & 59 & \\
$\mathrm{t} \mathrm{Stat}$ & -0.692877534 & \\
$\mathrm{P}(\mathrm{T}<=\mathrm{t})$ two-tail & 0.491104867 & \\
\hline
\end{tabular}

Source: Own elaboration.

Table 11. Paired two-sample t-test for comparison of mean return of the BSE 200 and multi-cap mutual funds

\begin{tabular}{lll}
\hline & BSE 200 & Multi Cap \\
\hline Mean & 0.890394425 & 1.119933239 \\
Variance & 16.32738851 & 16.75610639 \\
Observations & 60 & 60 \\
Pearson correlation & 0.970305757 & \\
Hypothesized mean difference & 0 & \\
df & 59 & \\
$\mathrm{t}$ Stat & -1.791409832 & \\
$\mathrm{P}(\mathrm{T}<=\mathrm{t})$ two-tail & 0.078356701 & \\
\hline
\end{tabular}

Source: Own elaboration.

\section{Conclusion}

This Study aims to empirically investigate the performance of prominent multi-capital and large-capital funds in India from 2013 to 2018. The performance of these two categories of Mutual funds is compared 
against India's most varied benchmark indices, such as BSE 200 and Nifty 500. To do so, we utilize the One-way Analysis of Variance (ANOVA) as an appropriate econometric methodology to compare the performance of mutual funds for a sample of 20 Indian mutual funds.

The empirical results of this Study reveal that the mutual fund schemes under both the categories, i.e., Multi Capital Funds and Large Capital Funds, have generated good returns over the period, with reasonable risk. Therefore, it is safe to conclude that they are a good investment option for an investor.

Regarding the performance of these mutual funds, the average monthly returns generated by the funds in each category are numerically different. However, this difference was not statistically significant (on applying Way ANOVA). As categories also, no statistically significant difference is observed between the means of average monthly returns of funds of multi Capital and large Capital categories. At the same time, there is no significant difference between these funds and NIFTY500, as well as these funds and BSE200 in terms of their returns.

The investors can use our empirical findings, traders, speculators, and directors of mutual funds to appreciate their investing project. Also, researchers can use our outcomes to develop their Study and validate their investigation.

This Study indicates that Multi Capital Funds and Large Capital Funds have important returns during the period of Study. However, to explain the generated returns, in future research, we should develop a comparative study between five categories of a mutual fund; mid \& small Capital, Large-Capital, multi Capital, infrastructure, and hybrid. Also, we can increase the sample by investigating a comparative study between India and other countries.

\section{Acknowledgements}

The authors wish to thank the Editor in Chief and anonymous referees whose valuable comments significantly improve the quality of the paper.

\section{Conflict of Interest}

The authors report no conflicts of interest. The authors alone are responsible for the content and writing of the paper. 


\section{References}

Agarwal, S., \& Mirza, N. (2017). A study on the risk-adjusted performance of mutual funds industry in India. Review of innovation and competitiveness, 3(1), 75-94. https://doi.org/10.32728/ric.2017.31/4

Ashraf, S. H., \& Sharma, D. (2014). Performance Evaluation of Indian Equity Mutual Funds against Established Benchmarks Index. International Journal of Accounting Research, 2(1), 1000113. https://doi.org/10.4172/2472-114X.1000113

Badrizadeh M., \& Paradi J.C. (2020). Pension Funds and Mutual Funds Performance Measurement with a New DEA (MV-DEA) Model Allowing for Missing Variables. In: Charles V., Aparicio J., Zhu J. (eds) Data Science and Productivity Analytics. International Series in Operations Research \& Management Science, 290, 391-413. https://doi.org/10.1007/978-3-030-43384-0 14

Busse, J.A., Chordia, T., Jiang, L., \& Tang, Y. (2020). Transaction Costs, Portfolio Characteristics, and Mutual Fund Performance, Management Science, Forthcoming. https://doi.org/10.1287/mnsc.2019.3524

Cujean, J. (2020). Idea sharing and the performance of mutual funds. Journal of Financial Economics, $135(1)$ 88-119. https://doi.org/10.1016/j.jfineco.2019.05.015

Damayanti, S.M. \& Cintyawati, C. (2015). Developing an Integrated Model of Equity Mutual Funds Performance: Evidence from the Indonesian Mutual Funds Market. GSTF Journal on Business Review (GBR), 6(2), 14-21. https://doi.org/10.7603/s40706-015-0016-3

Kumar, V., \& Kumar, A. (2012). Construction of Appropriate Benchmark Index for Mutual Funds: Specific Reference to Tax Saver Funds. International Journal of Financial Management, 2(1), 74-90. http://www.publishingindia.com/ijfm/30/construction-of-appropriatebenchmark-index-for-mutual-funds-an-empirical-analysis-with-specificreference-to-tax-saver-funds-elss/130/1032/

Nandhini, R. \& Rathnamani, Dr. V. (2017). A Study on the Performance of Equity Mutual Funds (With special reference to equity large cap and mid cap mutual funds). IOSR Journal of Business and Management, 19(2), 67-72. https://doi.org/10.9790/487X-1902026772

Narayanasamy, Dr. R. V. \& Rathnamani. (2013). Performance Evaluation of Equity Mutual Funds (On Selected Equity Large Cap Funds). International Journal of Business and Management Invention, 2(4), 18-24. https://doi.org/10.5281/zenodo. 1252910

Pandow, B. A. (2017). Performance of Mutual Funds in India. International Journal of Research in IT, Management and Engineering, 7(1), 14-23. http://indusedu.org/pdfs/IJRIME/IJRIME_1035_24314.pdf

Philips, C. B., \& Kinniry, F. M. Jr. (2010). Mutual fund ratings and future performance. Vanguard Research, Working research paper, No. 06/2010. https://www.stat.berkeley.edu/ aldous/157/Papers/mutual_funds.pdf 
Rangasamy, Dr. S., \& Sathiyapriya, M. (2017). Trend and performance of selected mutual funds. International Research Journal of Engineering and Technology, 4(2), 1651-1654. https://www.irjet.net/archives/V4/i2/IRJETV4I2324.pdf

(C) 2020 the Author(s). This is an open access article distributed under the terms of Creative Commons Attribution-Non Commercial License (CC BY-NC 4.0) which permits use, distribution and reproduction in any medium, provided the original work is properly cited and is not used for commercial purposes.

\section{Recommended citation:}

Derbali, A., K Elnagar, A., Jamel, L., \& Ben Ltaifa, M. (2020). Performance of Mutual Funds: A Comparative Study of Prominent Multi Capital and Large Capital Funds. Management \& Economics Research Journal, 2(4), 27-44. https://merj.com/merj/index.php/merj/article/view/123 